\title{
Hasil Tanaman Wortel (Daucus carota L.) di Dataran Rendah pada Berbagai Ketebalan Mulsa Jerami Padi
}

\author{
Yield of Carrot (Daucus carota L.) in Lowlands at Various Thicknesses \\ of Rice Straw Mulch
}

\author{
Ogy Farenza Ilham ${ }^{* 1}$, Jayaputra $^{2)}$, Aluh Nikmatullah ${ }^{1)}$, Bambang Budi Santoso ${ }^{2)}$ \\ 1) Program Studi Agroekoteknologi, Fakultas Pertanian, Universitas Mataram, Indonesia \\ 2) Kelompok Peneliti Bidang Ilmu Pengembangan Pertanian Lahan Kering, Fakultas Pertanian, \\ Universitas Mataram, Indonesia \\ *Corresponding Author Email: ogifarenza2@gmail.com
}

Manuscript received: 09-08-2021. Accepted: 26-10-2021

\begin{abstract}
ABSTRAK
Wortel merupakan salah satu sayuran yang disukai masyarakat karena memiliki banyak manfaat bagi kesehatan sehubungan kandungan vitamin $\mathrm{B}$, vitamin $\mathrm{C}$, dan zat-zat lain, sehingga meningkatkan kebutuhan atau permintaan, namun tidak seiring dengan peningkatan produksi dari tanaman ini. Salah satu usaha peningkatan produksi adalah melalui perluasan areal, dan dataran rendah merupakan sasaran pengembangannya. Penelitian ini bertujuan untuk mengetahui pertumbuhan dan hasil wortel yang ditanam di dataran rendah dengan mengaplikasikan mulsa jerami padi. Penelitian ini dilaksanakan pada areal persawahan, di Desa Bagek Polak, Kabupaten Lombok Barat, Nusa Tenggara Barat dengan ketinggian tempat $26 \mathrm{~m}$ dpl pada Juli-Oktober 2020. Percobaan lapang dengan metode eksperimental dirancang menurut Rancangan Acak Kelompok dengan satu faktor yaitu tingkat ketebalan mulsa jerami padi $(\mathrm{m} 0=$ tanpa mulsa jerami; $\mathrm{m} 1=$ ketebalan mulsa 1 lapis; $\mathrm{m} 2=$ ketebalan mulsa 2 lapis; $\mathrm{m} 3=$ ketebalan mulsa 3 lapis; $\mathrm{m} 4$ = ketebalan mulsa 4 lapis) diulang sebanyak 4 kali sehingga ada 20 unit percobaan. Hasil penelitian menunjukkan bahwa mulsa jerami padi berpengaruh nyata terhadap pertumbuhan dan hasil tanaman wortel di dataran rendah. Penggunaan mulsa jerami padi 4 lapis yang dapat meningkatkan pertumbuhan dan hasil tanaman wortel sebesar 2647,75 $\mathrm{gr} / \mathrm{m}^{2}$ atau setara 21,182 ton/ha).
\end{abstract}

Kata Kunci : lapisan; perluasan; produksi; sayuran; umbi

\begin{abstract}
Carrot is one of the vegetables that people like because it has many health benefits related to the content of B vitamins, vitamin C, and other substances, thereby increasing the need or demand, but not in line with the increase in the production of this plant. One of the efforts to increase production is through area expansion, and the lowlands are the target of its development. This study aims to determine the growth and yield of carrots grown in the lowlands by applying rice straw mulch. This research was conducted in a rice field area, in Bagek Polak Village, West Lombok Regency, West Nusa Tenggara with an altitude of $26 \mathrm{~m}$ above sea level in July-October 2020. The field experiment with the experimental method was designed according to a Randomized Block Design with one factor, namely the thickness of rice straw mulch. $(\mathrm{m} 0=$ no straw mulch; $\mathrm{m} 1=1$ layer mulch thickness; $\mathrm{m} 2=2$ layers mulch thickness;
\end{abstract}


$\mathrm{m} 3=3$ layers mulch thickness; $\mathrm{m} 4=4$ layers mulch thickness) was repeated four times so that there were 20 experimental units. The results showed that rice straw mulch had a significant effect on the growth and yield of carrots in the lowlands. The use of 4 layers of rice straw mulch was could increase the growth and yield of carrots by $2647.75 \mathrm{gr} / \mathrm{m} 2$ or the equivalent of $21,182 \mathrm{tons} / \mathrm{ha}$.

Keywords: layer; expansion; production; vegetables; tubers

\section{PENDAHULUAN}

Wortel merupakan salah satu sayuran yang disukai oleh masyarakat karena memiliki begitu banyak manfaat seperti mengandung vitamin $B$, vitamin $C$ serta zat-zat lain yang yang bermanfaat bagi kesehatan manusia. Umbi wortel sebagai bahan pangan untuk mengentasikan masalah kekurangan vitamin A, tumor atau kanker, kurang gizi, wortel memiiki rasa yang enak dan manis; hal ini menyebabkan meningkatknya permintaan terhadap komoditas wortel sangat besar baik di dalam ataupun di luar negeri akan tetapi tidak sejalan dengan peningkatan produksi dari tanaman ini.

Produksi wortel di Indonesia dalam 5 tahun terakhir berfluktuasi dan cendrung tetap , dari 512.112 ton pada tahun 2015 menjadi 495.800 ton pada tahun 2016, 522.529 ton pada tahun 2017, 537.526 ton pada tahun 2018 dan 537.341 ton pada tahun 2019 (BPS, 2017). Akan tetapi, produksi wortel di Nusa Tenggara Barat (NTB) malah menurun, dari 3274 ton pada tahun 2015 dengan total luas lahan panen 83 hektar menjadi 2149 ton pada tahun 2016 dengan total luas lahan panen 154 hektar. Selanjutnya, pada tahun 2017 produksi wortel di NTB mengalami penurunan yang sangat drastis menjadi 1422 ton dengan luas lahan 95 hektar, pada tahun 2018 mengalami kenaikan 2567 dan pada tahun 2019 mengalami penurunan kembali yaitu 2043 ton. Oleh karena itu perlu dilakukan usaha peningkatan produksi (BAPPEDA NTB, 2019). Produktivitas wortel di Nusa Tenggara Barat menurut BPS (2017), masih tergolong rendah sementara permintaan terhadap wortel semakin meningkat. Permintaan wortel pada tahun 2011 sebesar 526.917 ton, pada tahun 2014 menurun menjadi 495.800 ton dan pada tahun 2016 meningkat menjadi 537.526 ton seiring dengan bertambahnya jumlah penduduk dan kesadaran masyarakat akan pentingnya sayur-sayuran segar seperti wortel. Peningkatan produksi tanaman wortel dapat dilakukan dengan memperluas lahan penanaman. Agar dapat hidup dengan baik tanaman wortel (Daucus carota $\mathrm{L}$.) menghendaki suhu optimal $18-21{ }^{\circ} \mathrm{C}$, suhu udara tersebut di daerah tropis umumnya tercapai pada ketinggian 500-1000 meter diatas permukaan laut (mdpl). Upaya pengembangan wortel di dataran rendah bersuhu $>28{ }^{\circ} \mathrm{C}$ di Indonesia masih belum banyak dilakukan (Firmansyah, dkk. 2016).

Salah satu teknik budidaya untuk meningkatkan produksi tanaman wortel pada dataran rendah yaitu dengan memodifikasi iklim mikro di sekitar tanaman, salah satunya adalah dengan menggunakan mulsa, yang selain dapat memperbaiki iklim mikro, mulsa juga berfungsi dapat menghambat pertumbuhan gulma. Suminarti (2015) melaporkan bahwa aplikasi mulsa jerami berpengaruh nyata pada lingkungan mikro tanaman, khususnya kelembaban tanah dan suhu tanah serta pertumbuhan dan hasil tanaman talas. Informasi yang lebih detail terkait penggunaan mulsa jerami padi pada pertanaman wortel di dataran rendah sangat terbatas. Sehubungan dengan hal tersebut, diharapkan melalui uji ketebalan mulsa jerami padi ini akan diperoleh informasi tentang tingkat ketebalan mulsa yang tepat dalam upaya untuk mendapatkan lingkungan mikro yang sesuai untuk pertumbuhan dan hasil tanaman wortel yang ditanam di dataran rendah sehingga produktivitas hasil wortel dapat ditingkatkan. 


\section{Bahan dan Rancangan Percobaan}

\section{METODE PENELITIAN}

Benih yang digunakan dalam percobaan ini adalah benih wortel varietas lokal Gundalig Sumatra Utara. Benih yang digunakan adalah benih yang memiliki warna seragam, bersih mengkilat dan tidak cacat. Bahan mulsa berupa jerami padi yang telah kering (kadar air 7 - 9 Persen).

Metode yang digunakan dalam penelitian ini adalah metode eksperimental dengan percobaan di lapangan. Rancangan yang digunakan adalah Rancangan Acak Kelompok (RAK) dengan satu faktor yaitu beberapa tingkat ketebalan mulsa jerami padi antara lain $\mathrm{m} 0=0$ lapis (kontrol), $\mathrm{m} 1=$ ketebalan 1 lapis $\left(0.25 \mathrm{~kg} / \mathrm{m}^{2}\right), \mathrm{m} 2=$ ketebalan 2 lapis $\left(0.5 \mathrm{~kg} / \mathrm{m}^{2}\right), \mathrm{m} 3=$ ketebalan 3 lapis $\left(0.75 \mathrm{~kg} / \mathrm{m}^{2}\right)$ dan $\mathrm{m} 4=$ ketebalan 4 lapis $\left(1 \mathrm{~kg} / \mathrm{m}^{2}\right)$, sehingga didapatkan 5 kombinasi perlakuan yang masing-masing perlakuan diulang sebanyak 4 kali sehingga didapatkan 20 unit percobaan.

\section{Pelaksanaan Percobaan}

Lahan untuk budidaya wortel diolah dua kali. Pertama dibajak dengan menggunakan hand traktor dan lahan didiamkan selama satu minggu. Pengolahan kedua tanah dicangkul untuk menggemburkan tanah. Setelah tanah digemburkan dibuat bedengan dengan lebar 100 $\mathrm{cm}$, panjang $200 \mathrm{~cm}$, dan tinggi $30 \mathrm{~cm}$. Jarak antar bedengan dalam blok $20 \mathrm{~cm}$, jarak antar blok $40 \mathrm{~cm}$.

Penanaman benih dilakukan dengan sistem larikan yang dibuat sedalam $\pm 1 \mathrm{~cm}$ pada bedengan ke-arah lebar bedengan dengan jarak $20 \mathrm{~cm}$ antar larikan. Benih ditaburkan di atas larikan kemudian ditutup dengan tanah.

Pemasangan mulsa jerami dilukakan dengan cara meletakkan jerami padi di atas bedengan secara merata yang dilakukan pada pagi hari. Ketebalan mulsa diatur sesuai dengan perlakuan yang akan diujikan.

\section{Pemeliharaan pertanaman}

Penyiraman tanaman dilakukan dengan cara menyiram tanaman menggunakan gembor sampai tanah dalam keadaan kapasitas lapang atau terlihat lembab. Penyiraman dilakukan setiap hari yaitu pagi dan sore hari selama pertumbuhan wortel berlangsung.

Penjarangan dilakukan pada saat tanaman berumur 28 HST. Penjarangan dilakukan dengan cara mencabut tanaman yang tidak diinginkan atau sesuai dengan posisi jarak antar tanaman $20 \mathrm{~cm} \times 20 \mathrm{~cm}$. Bersamaan dengan penjarangan dilakukan pula penyiangan gulma.

Penyiangan gulma dilaku-kan dengan cara mencabut tumbuhan pengganggu (gulma) yang tumbuh pada areal bedeng percobaan.

Pemupukan tanaman berupa pupuk dasar menggunakan pupuk kandang ayam dengan dosis 10 ton/ha $\left(2 \mathrm{~kg} / \mathrm{m}^{2}\right)$. Setelah tanaman wortel tumbuh, kemudian dilakukan pemupukan susulan pertama menggunakan pupuk NPK Plus (16-16-16) dengan dosis $75 \mathrm{~kg} / \mathrm{ha}\left(15 \mathrm{gr} / \mathrm{m}^{2}\right)$ yang diberikan pada saat tanaman berumur 30 HST (setelah penjarangan). Kemudian pemupukan susulan ke-2 menggunakan pupuk NPK Plus (16-16-16) dengan dosis $75 \mathrm{~kg} / \mathrm{ha} \mathrm{(15}$ $\mathrm{gr} / \mathrm{m}^{2}$ ) pada saat tanaman berumur 50 HST.

Pencegahan hama dilakukan dengan menaburkan insektisida Furadan 3GR dengan dosis $2 \mathrm{~kg} / \mathrm{ha}\left(2,5 \mathrm{gr} / \mathrm{m}^{2}\right)$ ke permukaan bedengan dan kemudian diaduk sebatas permukaan tanah. Setelah penjarangan dilakukan penyemprotan tanaman dengan insektisida Metal $30 \mathrm{EC}$ ( $2 \mathrm{ml} / \mathrm{l}$ ) sedangkan untuk pencegahan penyakit pada tanaman disemprotkan fungisida Dithane M-45 80 WP (3 gr/l).

Pemanenan dilakukan pada saat tanaman berumur 85 HST. Pemanenan dilakukan dengan cara manual yaitu memegang tangkai daun tanaman wortel kemudian ditarik perlahan hingga tercabut umbinya. Pemanenan dilakukan pagi hari sebelum matahari terlalu terik. 


\section{Sampling dan analisis}

Penentuan tanaman sampel dilakukan dengan cara memilih sejumlah $10 \%$ tanaman tiap bedeng percobaan. Penentuan tanaman sampel dilakukan secara acak.

Parameter yang diamati dalam percobaan ini meliputi parameter pertumbuhan, parameter hasil, dan parameter kualitas hasil. Parameter pertumbuhan meliputi jumlah daun, tinggi tanaman, bobot basah tajuk, bobot kering tajuk, bobot basah umbi, bobot kering umbi, diameter umbi dan panjang umbi. Parameter hasil meliput bobot umbi per ubinan. Parameter kualitas hasil meliputi kadar gula umbi (keterlarutan bahan kasar dengan menggunakan Brix Refraktometer HB-512-ATC), dan tingkat kekerasan umbi (dengan Penetrometer GY-3). Suhu tanah, diukur dengan menggunakan thermometer batang.

\section{HASIL DAN PEMBAHASAN}

Pemakaian mulsa jerami pada berbagai ketebalan berpengaruh nyata terhadap tinggi tanaman wortel khususnya pada umur 28-84 HST. Sedangkan pada jumlah daun, bobot basah dan kering tajuk, bobot basah dan kering umbi, diameter umbi, dan panjang umbi, pemakaian mulsa jerami berpengaruh nyata sepanjang periode pertumbuhan tanaman wortel. Demikian pula pada kualitas hasil seperti tingkat kekerasan umbi dan kadar gula umbi, pemakaian mulsa jerami pada berbagai ketebalan berpengaruh nyata.

\section{Suhu Tanah}

Kondisi lingkungan tanaman yang berpengaruh terhadap pertumbuhan tanaman adalah salah satunya suhu yang spesifik untuk tumbuh (Edy, 2015). Pemakaian mulsa jerami pada permukaan bedeng tanaman wortel selama percobaan berpengaruh nyata pula pada suhu tanah selama periode pertumbuhan wortel (Tabel 1).

Tabel 1. Suhu tanah bedengan pada tiap ketebalan mulsa jerami padi

\begin{tabular}{|c|c|c|c|c|c|c|}
\hline \multirow[b]{2}{*}{$\begin{array}{l}\text { Ketebalan } \\
\text { Mulsa }\end{array}$} & \multicolumn{2}{|c|}{42 HST } & \multicolumn{2}{|c|}{63 HST } & \multicolumn{2}{|c|}{84 HST } \\
\hline & $\begin{array}{c}\text { Suhu Tanah } \\
\text { Pagi }^{\circ} \mathrm{C}\end{array}$ & $\begin{array}{l}\text { Suhu Tanah } \\
\text { Siang }{ }^{\circ} \mathbf{C}\end{array}$ & $\begin{array}{c}\text { Suhu Tanah } \\
\text { Pagi }^{\circ} \mathrm{C}\end{array}$ & $\begin{array}{l}\text { Suhu Tanah } \\
\text { Siang }{ }^{\circ} \mathrm{C}\end{array}$ & $\begin{array}{c}\text { Suhu Tanah } \\
\text { Pagi }^{\circ} \mathrm{C}\end{array}$ & $\begin{array}{c}\text { Suhu Tanah } \\
\text { Siang }{ }^{\circ} \mathrm{C}\end{array}$ \\
\hline Tanpa mulsa & $28.03 \mathrm{a}$ & $31.51 \mathrm{a}$ & $28.37 \mathrm{a}$ & $33.25 \mathrm{a}$ & $29.07 \mathrm{a}$ & $33.37 \mathrm{a}$ \\
\hline 1 lapis & $27.75 \mathrm{a}$ & $31.48 \mathrm{ab}$ & $28.33 \mathrm{~b}$ & $32.37 \mathrm{ab}$ & $28.62 \mathrm{a}$ & $32.37 \mathrm{~b}$ \\
\hline 2 lapis & $26.87 \mathrm{~b}$ & $30.25 \mathrm{bc}$ & $27.52 \mathrm{c}$ & $31.62 \mathrm{bc}$ & $28.05 \mathrm{~b}$ & $31.75 \mathrm{bc}$ \\
\hline 3 lapis & $26.07 \mathrm{c}$ & $29.87 \mathrm{~cd}$ & $27.07 \mathrm{~d}$ & $30.75 \mathrm{~cd}$ & $27.25 \mathrm{c}$ & $31.12 \mathrm{~cd}$ \\
\hline 4 lapis & $26.11 \mathrm{c}$ & $29.12 \mathrm{~d}$ & $27.02 \mathrm{~d}$ & $30.25 \mathrm{~d}$ & 27.14 & $30.53 \mathrm{~d}$ \\
\hline BNJ 5\% & 0.35 & 0.81 & 0.25 & 0.93 & 0.41 & 0.70 \\
\hline \multicolumn{2}{|c|}{ Komponen Syarat Tumbuh } & \multicolumn{3}{|c|}{ Referensi } & \multicolumn{2}{|c|}{ Sentra produksi (Karo) } \\
\hline \multirow{2}{*}{ Suhu } & Min. & & \multicolumn{2}{|c|}{$18,6^{\circ} \mathrm{C}$} \\
\hline & Mak. & \multicolumn{3}{|c|}{$30{ }^{\circ} \mathrm{C}$ (Putri, 2018) } & \multicolumn{2}{|c|}{$32,8^{\circ} \mathrm{C}$} \\
\hline \multirow{2}{*}{ Curah Hujan } & Min. & \multirow{2}{*}{\multicolumn{3}{|c|}{$\begin{array}{l}200 \mathrm{~mm} \text { (Prawito dan Susiani, 2006) } \\
300 \mathrm{~mm} \text { (Prawito dan Susiani, 2006) }\end{array}$}} & \multirow{2}{*}{\multicolumn{2}{|c|}{$\begin{array}{l}104 \mathrm{~mm} \\
443 \mathrm{~mm}\end{array}$}} \\
\hline & Mak. & & & & & \\
\hline
\end{tabular}

Keterangan: Angka yang diikuti dengan huruf yang sama pada kolom yang sama menunjukkan berbeda tidak nyata pada uji BNJ 5\%. HST = Hari Setelah Tanam

Pada Tabel 1 menunjukkan bahwa ketebalan mulsa jerami berpengaruh nyata terhadap suhu tanah pada umur 42 HST, 63 HST dan 84 HST baik itu suhu tanah pagi hari dan siang hari. Pada bedengan tanpa mulsa tampak suhu bedengan mencapai suhu paling tinggi dibandingkan dengan suhu bedengan yang bermulsa. Hal ini sejalan dengan pendapat Mardin \& Dewanto (2003) bahwa mulsa organik dapat meningkatkan kapasitas infiltrasi tanah 
sehingga kehilangan air dapat dikurangi dan menjaga suhu tetap stabil pada suhu tanah yang lebih rendah dari suhu tanah normal dan dapat meningkatkan kelembaban tanah.

Rinata (2018) menyatakan bahwa agar umbi wortel yang ditanam di dataran rendah dapat tumbuh dengan baik, maka suhu tanah tidak boleh lebih dari $30{ }^{\circ} \mathrm{C}$. Lebih lanjut, dia mengatakan bahwa suhu tanah terendah yaitu $26{ }^{\circ} \mathrm{C}$ sedangkan suhu tertinggi mencapai 33,37 ${ }^{\circ} \mathrm{C}$. Jadi pada percobaan ini, tanaman wortel dapat tumbuh dengan baik pada ketebalan $(2$ $\mathrm{kg} / \mathrm{m}^{2}$ ) dengan kisaran suhu $26-30,5^{\circ} \mathrm{C}$ dibandingkan dengan perlakuan kontrol (tanpa mulsa) yang memiliki suhu jauh lebih tinggi yaitu $28-33,7{ }^{\circ} \mathrm{C}$. Hal tersebut masih berada pada batas minimum dan maksimum suhu dari hasil deskripsi tanaman wortel varietas Gundaling yang di tanam di dataran tinggi Kabupaten Karo Provinsi Sumatera Utara dengan suhu minimum 18,6 ${ }^{\circ} \mathrm{C}$ dan maksimum $32,8{ }^{\circ} \mathrm{C}$. Sehingga pertumbuhan dan hasil tanaman wortel yang tumbuh dengan baik terdapat pada suhu tanah yang rendah yaitu pada ketebalan mulsa jerami padi 4 lapis $\left(1 \mathrm{~kg} / \mathrm{m}^{2}\right)$. Hal ini sejalan dengan pendapat Tinambunan (2014), daerah dengan suhu minimum $15{ }^{\circ} \mathrm{C}$ dan maksimum $30^{\circ} \mathrm{C}$ sangat baik untuk pertumbuhan tanaman umbi wortel, serta dapat diatur dengan menggunakan mulsa organik.

\section{Pertumbuhan Tanaman Wortel}

Ketebalan pemberian mulsa jerami berpengaruh nyata terhadap tinggi tanaman pada umur 28 HST- 84 HST (Tabel 2). Pada fase awal pertumbuhan, tinggi tanaman bermulsa lebih tinggi jika dibandingkan dengan tanpa pemberian pemulsaan. Berarti, dapat dikatakan bahwa semakin tebal penggunaan mulsa jerami maka semakin rendah suhu tanah dan semakin tinggi kelembaban tanah yang akan mempengaruhi pertumbuhan dan hasil tanaman wortel. Sesuai dengan apa yang dikatakan Eski dan Suryanto (2018).

Tabel 2. Tinggi tanaman dan laju pertumbuhan tinggi tanaman pada tiap perlakuan pemberian beberapa ketebalan mulsa jerami padi

\begin{tabular}{|c|c|c|c|c|c|c|}
\hline \multirow{2}{*}{$\begin{array}{c}\text { Ketebalan } \\
\text { Mulsa }\end{array}$} & \multicolumn{5}{|c|}{ Tinggi Tanaman $(\mathrm{cm})$} & \multirow{2}{*}{$\begin{array}{c}\text { LPTT } \\
(\mathrm{cm} / \mathrm{minggu})\end{array}$} \\
\hline & 28 HST & 42 HST & 56 HST & 70 HST & 84 HST & \\
\hline Tanpa mulsa (kontrol) & $17.08 \mathrm{a}$ & $25.62 \mathrm{a}$ & $34.16 \mathrm{a}$ & $42.7 \mathrm{a}$ & $51.24 \mathrm{a}$ & $4.27 \mathrm{a}$ \\
\hline 1 lapis $\left(0,25 \mathrm{~kg} / \mathrm{m}^{2}\right)$ & $17.2 \mathrm{ab}$ & $25.8 \mathrm{ab}$ & $34.4 \mathrm{ab}$ & $43 \mathrm{ab}$ & $51.6 \mathrm{ab}$ & $4.3 \mathrm{ab}$ \\
\hline 2 lapis $\left(0,5 \mathrm{~kg} / \mathrm{m}^{2}\right)$ & $17.84 \mathrm{ab}$ & $26.76 \mathrm{ab}$ & $35.68 \mathrm{ab}$ & $44.6 \mathrm{ab}$ & $53.52 \mathrm{ab}$ & $4.46 \mathrm{ab}$ \\
\hline 3 lapis $\left(0,75 \mathrm{~kg} / \mathrm{m}^{2}\right)$ & $17.96 \mathrm{~b}$ & $26.94 \mathrm{~b}$ & $35.92 \mathrm{~b}$ & $44.9 \mathrm{~b}$ & $53.88 \mathrm{~b}$ & $4.49 \mathrm{~b}$ \\
\hline 4 lapis $\left(1 \mathrm{~kg} / \mathrm{m}^{2}\right)$ & $18.08 \mathrm{~b}$ & $27.12 \mathrm{~b}$ & $36.16 \mathrm{~b}$ & $45.2 \mathrm{~b}$ & $54.24 \mathrm{~b}$ & $4.52 \mathrm{~b}$ \\
\hline BNJ 5\% & 0.83 & 01.25 & 1.67 & 2.08 & 2.50 & 0.20 \\
\hline
\end{tabular}

Keterangan: Angka yang diikuti dengan huruf yang sama pada kolom yang sama menunjukkan tidak berbeda nyata pada uji BNJ taraf 5\%. LPTT = Laju Pertumbuhan Tinggi Tanaman

Dari hasil penelitian ini, tinggi tanaman wortel yang di tanam di dataran rendah paling tinggi terdapat pada pemakaian mulsa 4 lapis atau $1 \mathrm{~kg} / \mathrm{m}^{2}$ yaitu $54.24 \mathrm{~cm}$, namun lebih pendek dari potensi genetiknya atau tanaman wortel yang di tanam di dataran tinggi Kabuaten Karo, Provinsi Sumatera Utara yaitu $110-116.5 \mathrm{~cm}$. Hal ini diduga karena tingkat pencahayaan di dataran rendah lebih tinggi dibandingkan dengan dataran tinggi sehingga mempengaruhi proses masak fisiologis, yaitu pada dataran rendah lebih cepat pertumbuhannya dibandingkan dengan dataran tinggi. Hal ini sesuai dengan pendapat Sitompul dan Guritno (1995), bahwa tinggi tanaman merupakan ukuran tanaman yang sering diamati sebagai indikator pertumbuhan maupun sebagai parameter untuk mengukur pengaruh lingkungan (cahaya dan $\mathrm{CO}_{2}$ ) atau perlakuan yang diterapkan karena tinggi tanaman merupakan ukuran pertumbuhan yang paling mudah dilihat. 
Tabel 3. Jumlah daun dan laju pertumbuhan jumlah daun pada tiap ketebalan mulsa jerami padi

\begin{tabular}{lcccccc}
\hline \multirow{1}{*}{$\begin{array}{c}\text { Ketebalan } \\
\text { Mulsa }\end{array}$} & \multicolumn{5}{c}{ Jumlah Daun } & LPJD \\
\cline { 2 - 6 } 28 HST & 42 HST & 56 HST & 70 HST & 84 HST & (helai/ minggu) \\
\hline Tanpa mulsa $(k o n t r o l)$ & $4.6 \mathrm{a}$ & $6.9 \mathrm{a}$ & $9.2 \mathrm{a}$ & $11.5 \mathrm{a}$ & $13.8 \mathrm{a}$ & $1,15 \mathrm{a}$ \\
1 lapis $\left(0,25 \mathrm{~kg} / \mathrm{m}^{2}\right)$ & $4.64 \mathrm{a}$ & $6.96 \mathrm{a}$ & $9.28 \mathrm{a}$ & $11.6 \mathrm{a}$ & $13.92 \mathrm{a}$ & $1,16 \mathrm{ab}$ \\
2 lapis $\left(0,5 \mathrm{~kg} / \mathrm{m}^{2}\right)$ & $4.96 \mathrm{~b}$ & $7.44 \mathrm{~b}$ & $9.92 \mathrm{~b}$ & $12.4 \mathrm{~b}$ & $14.88 \mathrm{~b}$ & $1,24 \mathrm{ab}$ \\
3 lapis $\left(0,75 \mathrm{~kg} / \mathrm{m}^{2}\right)$ & $5.2 \mathrm{c}$ & $7.8 \mathrm{c}$ & $10.4 \mathrm{c}$ & $13 \mathrm{c}$ & $115.6 \mathrm{c}$ & $1,3 \mathrm{~b}$ \\
4 lapis $\left(1 \mathrm{~kg} / \mathrm{m}^{2}\right)$ & $5.32 \mathrm{c}$ & $7.98 \mathrm{c}$ & $10.64 \mathrm{c}$ & $13.3 \mathrm{c}$ & $15.96 \mathrm{c}$ & $1,33 \mathrm{~b}$ \\
\hline BNJ $5 \%$ & 0.15 & 0.22 & 0.30 & 0.37 & 0.45 & 0,03 \\
\hline
\end{tabular}

Keterangan: Angka yang diikuti dengsn huruf yang sama pada kolom yang sama menunjukkan berbeda tidak nyata pada

uji BNJ taraf 5\%. LPJD = Laju Pertumbuhan Jumlah Daun

Pertumbuhan daun dalam hal ini jumlah daun dipengaruhi ketebalan pemberian mulsa jerami (Tabel 3). Pemberian jerami meningkatkan kelembapan tanah dan menciptakan lingkungan yang berbeda dan mencegah kehilangan air dibandingkan dengan tanpa pemberian mulsa jerami. Selain itu, pemakaian mulsa jerami lebih dapat menjamin ketersedian unsur hara pada tanah. Hal ini sesuai dengan pendapat Mardin \& Dewanto (2013) komposisi kandungan unsur hara seperti Nitrogen, Phosfor, Kalium, Kalsium, dan Magnesium akan lebih tersedia pada bedengan bermulsa dibandingkan tanpa mulsa. Ketersediaan mulsa membuat jumlah daun wortel akan semakin meningkat. Pada Tabel 3 menunjukkan bahwa pemakaian mulsa jerami berpengruh nyata terhadap jumlah daun dari 28-84 HST. Jumlah daun paling banyak terdapat pada pemakaian mulsa jerami 4 lapis $\left(1 \mathrm{~kg} / \mathrm{m}^{2}\right)$ dan jumlah daun paling sedikit terdapat pada bedengan tanpa mulsa.

Table 4. Panjang umbi dan diameter umbi pada tiap perlakuan pemberian beberapa ketebalan mulsa jerami padi

\begin{tabular}{lcl}
\hline \multicolumn{1}{c}{ Ketebalan Mulsa } & Panjang Umbi (cm) & Diameter Umbi (cm) \\
\hline Tanpa mulsa $(\mathrm{kontrol})$ & $14.48 \mathrm{a}$ & $2.44 \mathrm{a}$ \\
1 lapis $\left(0,25 \mathrm{~kg} / \mathrm{m}^{2}\right)$ & $14.96 \mathrm{a}$ & $2.43 \mathrm{a}$ \\
2 lapis $\left(0,5 \mathrm{~kg} / \mathrm{m}^{2}\right)$ & $15.52 \mathrm{a}$ & $2.73 \mathrm{ab}$ \\
3 lapis $\left(0,75 \mathrm{~kg} / \mathrm{m}^{2}\right)$ & $15.34 \mathrm{a}$ & $2.76 \mathrm{ab}$ \\
4 lapis $\left(1 \mathrm{~kg} / \mathrm{m}^{2}\right)$ & $16.68 \mathrm{~b}$ & $2.95 \mathrm{~b}$ \\
\hline BNJ $5 \%$ & 1.06 & 0.49
\end{tabular}

Keterangan: Angka yang diikuti dengsn huruf yang sama pada kolom yang sama menunjukkan berbeda tidak nyata pada uji BNJ taraf 5\%.

Pada Tabel 4 menunjukkan bahwa pemakaian mulsa jerami padi pada berbagai ketebalan berpengaruh nyata terhadap panjang umbi dan diameter umbi. Umbi paling panjang dihasilkan pada ketebalan mulsa jerami 4 lapis $(1 \mathrm{~kg} /$ bedeng) yaitu $16.68 \mathrm{~cm}$ sedangkan yang paling rendah dihasilkan pada tanpa mulsa jerami padi yaitu $14.48 \mathrm{~cm}$. Demikian pula halnya dengan diameter umbi terbesar dihasilkan pada ketebalan mulsa jerami padi 4 lapis $\left(1 \mathrm{~kg} / \mathrm{m}^{2}\right)$ yaitu $2.95 \mathrm{~cm}$, dan terendah terdapat pada perlakuan tanpa mulsa jerami padi yaitu $2.44 \mathrm{~cm}$.

Dari hasil penelitian ini, bentuk umbi wortel varietas Gundaling yang ditanam di dataran rendah yaitu bulat memanjang, pangkal bulat dan tumpul, ujung umbi kecil dan tajam berbeda dengan bentuk umbi varietas Gundaling yang di tanam di dataran tinggi yang bentuk umbinya 
bulat memanjang, pangkal dan ujung tumpul. Hal ini di sebabkan karena kondisi suhu udara di dataran rendah yang tinggi sehingga menyebabkan pertumbuhan umbi yang kurang baik.

Table 5. Berat basah tajuk, berat kering tajuk, berat basah umbi dan berat kering umbi pada tiap perlakuan pemberian beberapa ketebalan mulsa jerami padi

\begin{tabular}{lcccc}
\hline Ketebalan Mulsa & $\begin{array}{c}\text { Bobot Basah } \\
\text { Umbi (gr) }\end{array}$ & $\begin{array}{c}\text { Bobot Kering } \\
\text { Umbi (gr) }\end{array}$ & $\begin{array}{c}\text { Bobot Basah } \\
\text { Tajuk (gr) }\end{array}$ & $\begin{array}{c}\text { Bobot Kering } \\
\text { Tajuk (gr) }\end{array}$ \\
\hline Tanpa mulsa & $82.73 \mathrm{a}$ & $8.78 \mathrm{a}$ & $53.22 \mathrm{a}$ & $9.96 \mathrm{a}$ \\
(kontrol) & $88.6 \mathrm{ab}$ & $9.16 \mathrm{a}$ & $74.5 \mathrm{bc}$ & $12.41 \mathrm{~b}$ \\
1 lapis $\left(0,25 \mathrm{~kg} / \mathrm{m}^{2}\right)$ & $93.82 \mathrm{~b}$ & $10.32 \mathrm{ab}$ & $70.65 \mathrm{~b}$ & $12.26 \mathrm{~b}$ \\
2 lapis $\left(0,5 \mathrm{~kg} / \mathrm{m}^{2}\right)$ & $105.4 \mathrm{c}$ & $10.95 \mathrm{~b}$ & $80.17 \mathrm{c}$ & $15.22 \mathrm{c}$ \\
3 lapis $\left(0,75 \mathrm{~kg} / \mathrm{m}^{2}\right)$ & $116.62 \mathrm{~d}$ & $12.92 \mathrm{c}$ & $78.20 \mathrm{bc}$ & $15.55 \mathrm{c}$ \\
4 lapis $\left(1 \mathrm{~kg} / \mathrm{m}^{2}\right)$ & 10.50 & 1.72 & 8.16 & 1.55 \\
\hline BNJ $5 \%$ & &
\end{tabular}

Keterangan: Angka yang diikuti dengsn huruf yang sama pada kolom yang sama menunjukkan berbeda tidak nyata pada uji BNJ taraf 5\%. BB = Berat Basah, BK = Berat Kering.

Bahwa ketebalan mulsa jerami padi berpengaruh nyata terhadap berat basah umbi, berat kering umbi, berat basah tajuk dan berat kering tajuk (Tabel 5). Bobot basah umbi paling tinggi terdapat pada ketebalan mulsa jerami padi $1 \mathrm{~kg} / \mathrm{m}^{2}$ dan paling ringan terdapat pada tanpa mulsa. Suhu tanah berhubungan dengan proses penyerapan unsur oleh akar, fotosintesis, dan respirasi.

Hasil penelitian ini menunjukkan, bahwa bobot umbi wortel yang ditanam di dataran rendah paling berat terdapat pada perlakuan ketebalan mulsa jerami 4 lapis $(1 \mathrm{~kg} / \mathrm{bedeng})$ sebesar $116.62 \mathrm{~g}$. Namun hasil tersebut masih lebih rendah dari potensi genetik tanaman wortel yang ditanam di dataran tinggi yaitu sebesar 120-250 g. Hal ini di sebabkan karena wortel yang di tanam di dataran rendah memiliki tingkat kelembaban yang rendah di bandingkan dengan tanaman wortel yang di tanam di dataran tinggi sehingga menyebabkan umbi cepat masak secara fisiologis sebelum mencapai volume umbi yang maksimal.

\section{Hasil Tanaman Wortel}

Hasil tanaman wortel dipengaruhi oleh beberapa faktor yaitu faktor internal dan faktor eksternal. Faktor internal adalah faktor yang berasal dari tanaman itu sendiri seperti sifat genetik dan lainnya. Sedangkan faktor eksternal yaitu faktor yang berasal dari luar tanaman atau dari lingkungan tanaman seperti suhu tanah, kelembaban serta faktor abiotik. Faktor abiotik yaitu faktor yang disebabkan oleh manusia seperti pemupukan, pemberian mulsa, penyiangan gulma dan lain-lain.

Table 6. Bobot umbi per ubin pada tiap ketebalan mulsa jerami padi

\begin{tabular}{lc}
\hline \multicolumn{1}{c}{ Ketebalan Mulsa } & Bobot Umbi Per Ubin $\left(\mathbf{g} / \mathbf{m}^{2}\right)$ \\
\hline Tanpa mulsa $($ kontrol $)$ & $1945.25 \mathrm{a}$ \\
1 lapis $\left(0.25 \mathrm{~kg} / \mathrm{m}^{2}\right)$ & $1984.25 \mathrm{a}$ \\
2 lapis $\left(0.5 \mathrm{~kg} / \mathrm{m}^{2}\right)$ & $2187.75 \mathrm{ab}$ \\
3 lapis $\left(0.75 \mathrm{~kg} / \mathrm{m}^{2}\right)$ & $2349.00 \mathrm{~b}$ \\
4 lapis $\left(1 \mathrm{~kg} / \mathrm{m}^{2}\right)$ & $2647.75 \mathrm{c}$ \\
\hline BNJ $5 \%$ & 294.78 \\
\hline
\end{tabular}

Keterangan: Angka yang diikuti dengsn huruf yang sama pada kolom yang sama menunjukkan berbeda tidak nyata pada uji BNJ taraf $5 \%$. 
Hasil penelitian ini juga menunjukkan bahwa ada pengaruh nyata ketebalan mulsa jerami padi terhadap bobot umbi per ubin (Tabel 6). Bobot umbi per ubin tertinggi dihasilkan pada ketebalan mulsa jerami 4 lapis $\left(1 \mathrm{~kg} / \mathrm{m}^{2}\right)$ yaitu $2647.75 \mathrm{gr} / \mathrm{m}^{2}$ atau $21.182 \mathrm{ton} / \mathrm{ha}$., dan terendah terdapat pada tanpa mulsa yaitu $1945.25 \mathrm{gr} / \mathrm{m}^{2}$ atau 15.562 ton/ha. Bobot umbi per ubin tertinggi yang di tanaman di dataran rendah masih lebih rendah dibandingkan hasil produksi wortel yang di tanam di dataran tinggi Kabupaten Karo Provinsi Sumatera Utara yaitu sebesar 25-30 ton/ham. Hal ini diduga karena pemberian mulsa jerami padi dapat menurunkan suhu tanah, meningkatkan kelembaban tanah dan meningkatkan unsur hara tanah sehingga umbi wortel dapat terbentuk dengan baik.

Pemakaian mulsa jerami sangat berpengaruh terhadap suhu tanah. Pemakaian mulsa jerami padi secara langsung dapat meningkatkan kelembaban tanah sehingga air yang terdapat pada dalam tanah dapat diserap secara optimal oleh tanaman dan berpengaruh terhadap tingkat kekerasan umbi dan kadar gula umbi.

Table 7. Kadar gula dan kekerasan umbi pada tiap ketebalan mulsa jerami padi

\begin{tabular}{lcc}
\hline \multicolumn{1}{c}{ Ketebalan Mulsa } & $\begin{array}{c}\text { Kadar Gula Umbi } \\
(\mathbf{0} \text { Brix })\end{array}$ & $\begin{array}{c}\text { Kekerasan Umbi } \\
\left(\mathbf{g} / \mathbf{d e t i k} / \mathbf{c m}^{2}\right)\end{array}$ \\
\hline Tanpa mulsa $(\mathrm{kontrol})$ & 11.05 & 3.92 \\
1 lapis $\left(0,25 \mathrm{~kg} / \mathrm{m}^{2}\right)$ & 10.32 & 3.87 \\
2 lapis $\left(0,5 \mathrm{~kg} / \mathrm{m}^{2}\right)$ & 10.45 & 3.85 \\
3 lapis $\left(0,75 \mathrm{~kg} / \mathrm{m}^{2}\right)$ & 10.25 & 3.80 \\
4 lapis $\left(1 \mathrm{~kg} / \mathrm{m}^{2}\right)$ & 9.95 & 3.72 \\
\hline BNJ $5 \%$ & - & - \\
\hline
\end{tabular}

Keterangan: Angka yang diikuti dengsn huruf yang sama pada kolom yang sama menunjukkan berbeda tidak nyata pada uji BNJ taraf 5\%.

Terdapat perbedaan nyata pada kadar gula umbi dan kekerasan umbi akibat adanya perbedaan pemberian mulsa jerami padi (Tabel 7). Tingkat kemanisan secara kuantitatif dapat di wakili oleh nilai kadar gula yang ternilai oleh alat dalam satuan ${ }^{\circ}$ Brix. Menurut Firmansyah (2016), terdapat empat tingkatan kemanisan untuk umbi wortel, yaitu buruk ( $\left.<5^{\circ} \mathrm{Brix}\right)$, sedang (5-9 ${ }^{\circ}$ Brix), baik (9-15 ${ }^{\circ}$ Brix) dan sangat baik ( $>15^{\circ}$ Brix). Jadi berdasarkan klasifikasi tingkat kemanisan tersebut, maka hasil penelitian ini menunjukkan bahwa umbi-umbi wortel baik yang tanpa mulasa maupun bermulsa berbeda ketebalannya, memiliki tingkat kemanisan yang baik (9-15 ${ }^{\mathrm{O}}$ Brix). Demikian pula halnya dengan tingkat kekerasan umbi wortel pada penelitian ini menunjukkan kisaran kekerasan yang tidak berbeda.

\section{KESIMPULAN}

Ketebalan mulsa jerami padi berpengaruh nyata terhadap pertumbuhan dan hasil tanaman wortel yang ditanam pada dataran rendah. Bobot hasil tanaman wortel terbaik yaitu sebesar $2647.75 \mathrm{~kg} / \mathrm{m}^{2}$ atau $21.182 \mathrm{ton} / \mathrm{ha}$. diperoleh dengan melapiskan permukaan bedengan sebanyak empat lapis jerami padi ataun setara $1 \mathrm{~kg} / \mathrm{m}^{2}$ bobot kering jerami.

\section{DAFTAR PUSTAKA}

Andriani, P., Suryanto, A. dan Sugito, Y. 2013. Uji Metode Pengolahan Tanah Terhadap Hasil Wortel (Daucus carota L.). Jurnal Produksi Tanaman. 1(5). www.protan.studentjurnal.ub.ac.id/index.

Azami, M.A. and S. Mohammadi. 2008. Determination of The Best Temperature and Dry Condition in Carrot. Pakistan Journal of Biological Sciences. 11(11): 1502 -1505. 
Aziiz, A. Herlina, N. dan Edy. S.N. 2018. Pengaruh Tingkat Ketebalan Mulsa Jerami Pada Tanaman Kacang Hijau (Vigna radiate L.). Jurnal Produksi Tanaman. 6(4): 524-530.

Badan Pusat Statistik, 2017. Produksi Tanaman Sayur-Sayuran di Indonesia. www.bps.go.id. [15 Desember 2019].

Balai Penelitian Tanah. 2009. Jerami dapat mensubstitusi pupuk KCl. Warta Penelitian dan Pengembangan Pertanian. 31(1): 3-5.

Bappeda NTB. 2019. NTB Dalam Angka. Badan Perencanaan Pembangunan Daerah. Mataram.

Booth, B.D., S.D. Murphy and C.J. Swanton. 2003. Weed Ecology in Natural Agriculture System. CABI Publishing Cambridge USA.

Edy, N.S. 2015. Pengaruh Tingkat Ketebalan Mulsa Jerami Pada Pertumbuhan dan Hasil Tanaman Talas (Colocasia esculenta L.) Schott var. Antiquorum. Jurnal Argo, 2(2): 4653.

Firmansyah, M. A., Liana, T. and Rahayu. 2016. Uji Adaptasi Wortel di Tanah Lempung Liat Berpasir Dataran Rendah Palangka Raya. J. Hort. 26(2): 197-206.

Gardner, P. F, R. B Preace and R. L. Mitchell. 1991. Phyciology of Crop Plant, terjemahan Fisiologi Tanaman Budidaya. Universitas Indonesia. Jakarta.

Goldsworthy, S. Y., Fisher, 1992. Pertumbuhan dan Produksi Ubi Jalar di Dataran Rendah Pada Berbagai Varietas dan Sumber Stek. J. Agrivigor 10(3): 228-234.

Mardin, S. dan Dewanto, E. 2013. Kajian Dosis Pupuk Organic Cair Leachate Plus Dan Ketebalan Mulsa Untuk Pertumbuhan Dan Hasil Wortel Di Dataran Rendah. Agrin. 17(1): 333-341.

Rinata M. E. (2018). Pengaruh Tingkat Ketebalan Mulsa Jerami pada Tanaman Wortel (Daucus carota L. var. New Kuoroda) dengan Ketinggian Berbeda. Jurnal Produksi Tanaman. 6(4): 553-560.

Suminarti, N.E. 2015. Pengaruh tingkat ketebalan mulsa jerami pada pertumbuhan dan hasil tanaman talas (Colocasia esculenta (L.) Schott var. Antiquorum). Jurnal Agro. 2(2): $1-13$

Surajuddin, M. dan S. A. Lasmini. 2010. Respon Pertumbuhan dan Hasil Jagung Manis (Zae mays saccharata) Pada Berbagai Waktu Pemberian Pupuk Nitrogen dan Ketebalan Mulsa Jerami. J. Agroland. 17(3): 184-.91,

Tinambunan E. 2014. Pengunaan Berberapa Jenis Mulsa terhadap Produksi Baby (Daucus carota L.) Varieats Hibrida. Jurnal Produksi Tanaman. 2(1): 26-30. 